本自動注入装置の最大の特徵は透明なディスポーザブ ル注射筒定使用した点にあり，手注入と全く同じように 妄心して使用できます。故に，本装置はこの利点孛非か

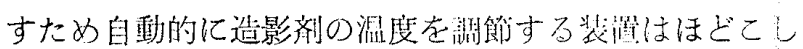
ておりません。

\section{9. 電場発光膜挿入形ネームプリンターの研究}

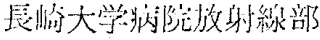

高在 我人

目的 X線写真に患者のネーム在より合栵的で碎事に 入れるための方式老研究開発した。

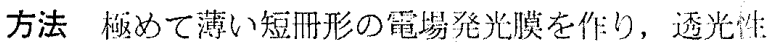
の紙に記入したネームを電埸発光膜上西称て，カセッテ の側面に設けた僬光空からカセッテ内のX線フィルムと 重なるように插入して電場癸炎膜に電压を打わえて発光

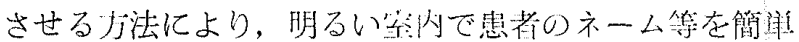
に確来に焼付ける構造しした。

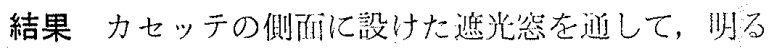
い室内で電場発光膜よネームカードを力七ッテ内に㧴入 してスイッチを入れるだけでネームの烧付けが完了する ので，間造いを生ずることがなく，訬めて能率的でもあ る。な扔，ネームの位置の増感紙を戗り取りフロント堌 感紙側に 0.3 ミリの鉛板を接着すれば，值揬X線による ネーム烧付部分のカブリは実用上企く問题にならない，

[特竍出願済]

\section{0. 高圧自動注入器の注入速度比較テスト}

\section{儿大病院中夯放射線碚 新開 获否}

䐘血管，心血管，胸部血管，腈部仙管等の撮影には， ほとんどの場合, 高王自動注入器を使用していますが, 使用カテーテルや造影剂によって，その注入速度は，ど の様に変化するのか，3種類の淮入器について, 次の 4 項目のテストを行いました.

高死自動注入器の種類

\section{Elema Schönander Gidlund}

2. Elema Schönander Cisal $50 \mathrm{cc}$ Syringe

3. Elema Schönander Cisal 10cc Syringe テスト項目

1. カテーテルの内径による変化

2. カテーテルの長さによる変化

3. 造影剂の濃度による変化

4. 造影剤の温度による変化

結果 注入器の高王ガス Syringe 造影剂 Syringe のピストンの面積の比によって屯注入速度は変りますの
で，乙れらの值を十分認識した上で留压自動往入器の特 这を纵かして使用すべきではないでしょうか。しかし注 人速度变える因子は，血管の内压，力テーテルの先の 玥状等まだまだ沃山ありますので，これらの因子を命後 |分检部したい.

\section{1. 手術中造影像の即時観測法検討}

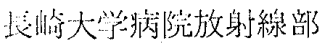
高尼 義人

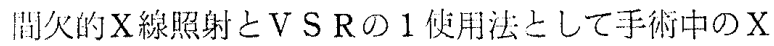
線撮影にかわるパルス状X線による透視像のV S R 録面 再生法について述べる。即ち手術中にX線写真撮影を䒠

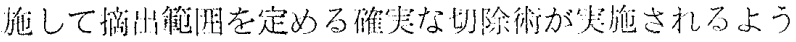
になり写真処㙕の急速化が望ま机，迅速现像処理装墔が

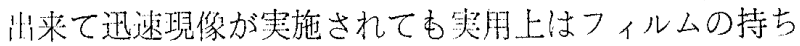

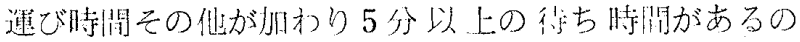
で，開腹した状態でこの様な掫影を们回むくりかえすこ とは不问能である.

この様な時】，Iまたは篮光柀上組介せたテレビカメ ラの任意の1フレームのビデオ信号をV S Rに録西泪米 る棈造しし，X線炎生器で 0.1 秒程度のX線照射をする と其に 0.1 秒のX線照射の終りに近い1フレームのビデ

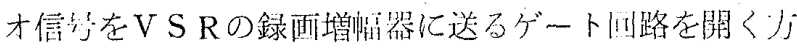

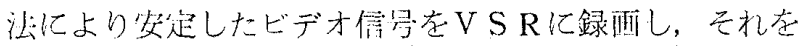

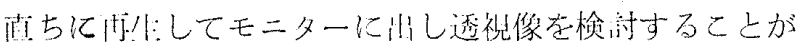
屿来る。

12. 逆行性腸透視用造影剂自動注排泄装置の開発（第 $\mathrm{N}$ 報）

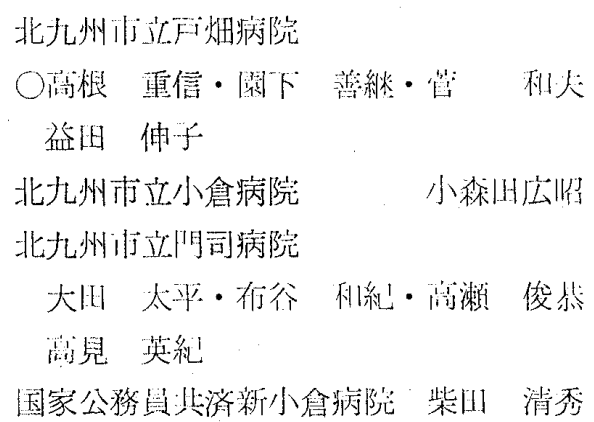

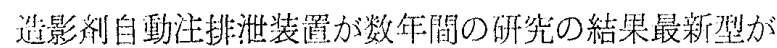
完成したので第 $\mathrm{N}$ 報として㯇告する。装置の概略，造影

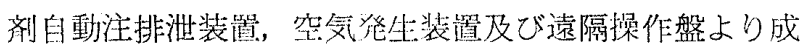
っている。

1. 造影剂白動注排泄装留 直腸力テーテルの来端を 3 j管の一端に継ぎ，残り 3 少をBa注入，空氛注入， 排泄のそれぞれのゴム管に接続してソレノイドを用いて ゴム管を王迫閉塞，開放を行い $\mathrm{Ba}$ 注入，空気注入，排 泄を自動的飞行う。 